\title{
A short review on the development of novel face masks during COVID-19 pandemic
}

Gorakh Sawant ${ }^{1}$, Kumar Gaurav $^{2}$, Gaurav Mittal $^{1}$, Ashish Karn ${ }^{1, *}$

${ }^{1}$ Department of Aerospace Engineering, School of Engineering, University of Petroleum and Energy Studies, Dehradun, India, 248007

${ }^{2}$ Department of Mechanical Engineering, School of Engineering, University of Petroleum and Energy Studies, Dehradun, India, 248007

* Email addresses of the corresponding author: akarn@ddn.upes.ac.in

\begin{abstract}
COVID-19 pandemic has emerged as a challenging situation for the entire world. This paper has covered outbreak of SARS and MERS coronavirus in the past, their effect on communities and preventive guideline by WHO, CDC and governments agencies. This paper also includes comparison of SARS CoV-2 which is driving current pandemic with SARS CoV and MERS $\mathrm{CoV}$. The effect of COVID-19 pandemics across the globe are also highlighted in this paper. A review on various preventive measures and their impact on controlling a pandemics has been discussed. During a pandemic, face masks plays a key role in controlling the spread of virus from one person to another. The effect of wearing mask on the decrease in number of cases during the pandemic has been quantified. A comparative study of effectiveness of different masks has also been covered in this paper. Various novel face masks that have emerged during the COVID-19 pandemic has also been discussed in the current manuscript.
\end{abstract}

Keywords: Novel Facemask, COVID-19, Faceshield, facemask design 


\section{Introduction}

Global outbreak of disease such as Viral hemorrhagic fevers, Zika virus epidemic, small pox, influenza including swine flu, Asian flu, Hong Kong Flu, Spanish flu etc. has been encountered by the humankind in the past. Currently world is facing COVID-19 pandemic, which is due to the spread of a coronavirus called SARS CoV-2. Coronaviruses are a family of RNA viruses which is responsible for causing diseases in mammals and birds. These viruses have been transferred from animals to human, and have caused respiratory diseases ranging from mild diseases like common cold to severe diseases like SARS, MERS and COVID-19. Coronavirus is of spherical structure with diameter around 125 micron. It has an envelope of diameter around 85 micron which is surrounded by 20 micron long spikes. [1]. Coronavirus have around 74 spikes on the surface of its envelope. [2].

Presently eight categories of coronaviruses have been found which can cause illness to human i.e. HCoV-NL63, HCoV-229E, HCoV-OC43, HCoV-HKU1, SARS-CoV, MERS-CoV, SADS-CoV and SARS CoV-2. Bat is the natural host for all the coronaviruses except HCoVOC43 and HCoV-HKU1 which was first found in rats [3]. Generally the coronaviruses are responsible for causing mild diseases such as cold, diarrhoea etc. but SARS CoV, MERS CoV and SARS CoV-2 was found responsible for severe fatal respiratory related diseases. Severe acute respiratory syndrome (SARS) was first detected in February 2003, during global outbreak of severe pneumonia associated with human deaths. Middle East Respiratory Syndrome (MERS) was started from Saudi Arabia in 2012. At present the world is facing the outbreak of SARS CoV-2. The virus attacks the upper respiratory system of human, which can also be fatal in some cases. The disease is named by WHO as COronaVIrus Disease 2019 (COVID-19). Initial cases of COVID-19 was reported in Wuhan, China in Dec 2019.

During various pandemics, governments around the world have taken serious protective measures to stop the transmission of virus among humans. Maintaining social distancing, proper hand hygiene, use of face mask and proper cough etiquettes are proven to be effective and advised by global health organisations such as WHO and CDC. Face masks play key role in minimize the transmission of virus from one person to another where social distancing cannot be maintained. Government of various countries announces the compulsorily use of masks in public places. Masks have proven to be very effective in restricting the virus from 
reaching respiratory track via mouth or nose. Mask only allow air particles to go through it, and the virus gets stuck at the outer surface of mask.

Mask use various air filtration mechanism such as straining, inertial impaction, interception, diffusion and electrostatic attraction. Straining, inertial impaction, and interception are the dominant collection mechanisms for particles greater than 0.2 microns whereas diffusion is dominant for particles less than 0.2 microns. Straining occurs when the gap between the media members is kept smaller than the diameter of the particulate, therefore these particles can be captured outside the mask as shown in Fig 1(a). Inertial Impaction uses a rapid change in air direction and the principles of inertia to separate the particulate from the air stream. Particles at a certain velocity tend to remain at velocity and travel in a continuous direction as shown in Fig 1(b). This principle is normally applied when there is a high concentration of coarse particulate. Figure 1(c) shows the phenomenon of interception in which the particulate make physical contact and remain attached to the media fiber. The particulate which is intercepted is smaller and its inertia is not strong enough to cause the particle to continue in a straight line. It, therefore, follows the air stream until it comes into contact with a fiber. The phenomenon of diffusion is shown in Fig. 1(d) in which the gas molecules collide with the smallest particles, especially those below 100 micron in diameter, which are thereby impeded and delayed in their path through the filter, increasing the probability of capturing of that particle. Electrostatic attraction, also called electrostatic precipitation involves using certain resins, waxes, and plastics as coatings on the filter material to attract particles with an electrostatic charge that holds them on the filter surface as shown in Fig 1(e). In most of the masks a layer of electret is kept to filter the substrate by electrostatic attraction. This technique is used for the removal of very fine particulates such as dust and smoke. [4]

(a)

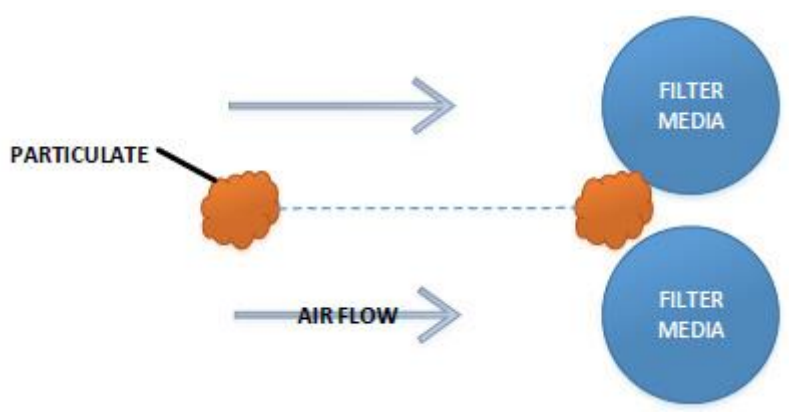


(b)

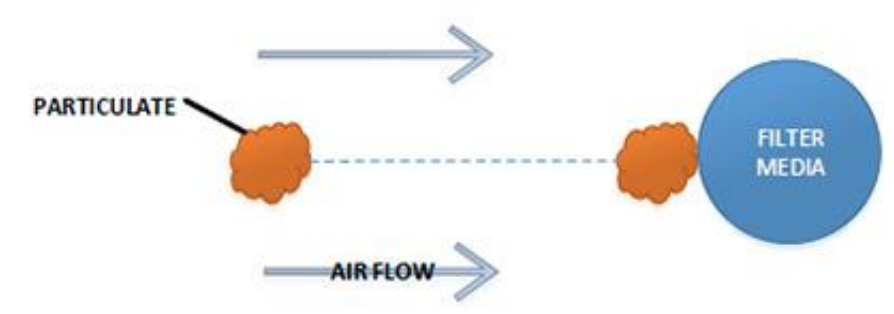

(c)

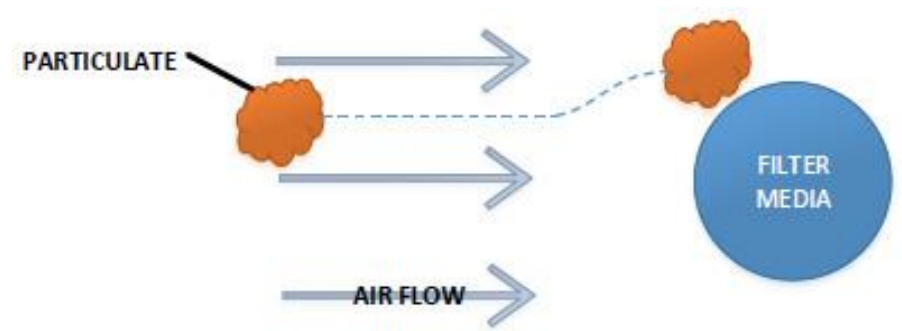

(d)

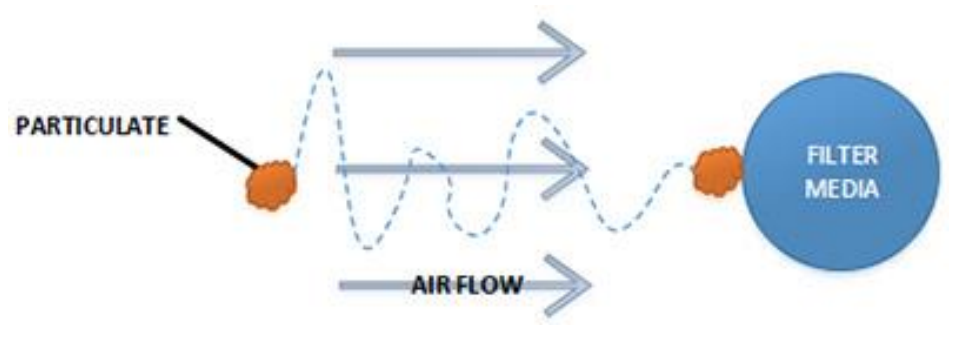

(e)

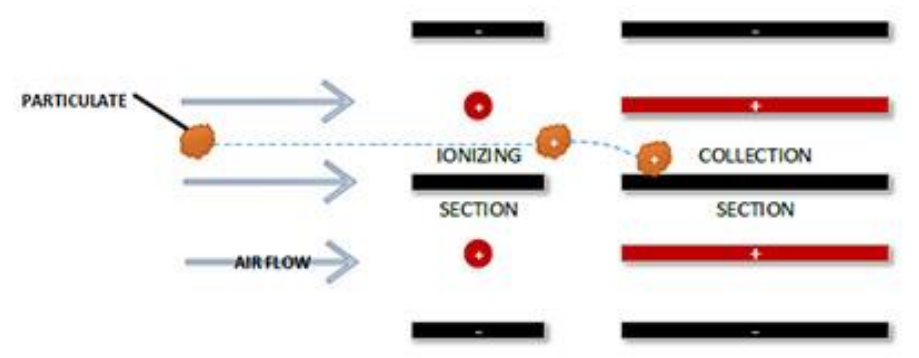

Fig 1: A schematic demonstrating various air filtration phenomenon: (a) Straining, (b) Inertial impaction, (c) Interception, (d) Diffusion, and (e) Electrostatic attraction [4]

The face masks can be broadly divided into three different categories: (i) cloth face masks, (ii) surgical mask and (iii) N95 mask.

i. Cloth mask: Cloth mask can be made at home with the use of available cloth material. These mask are helpful restricting an infected person to transmit their viruses during talking, coughing or sneezing to another person or nearby objects. However possesses very low effectiveness in restricting the virus to reach wearer nose or mouth. Still wearing a cloth face mask is a far better choice than not using any mask. Due to sudden increase in the demand of N95 respirator, CDC has recommended the use of cloth face mask by people in public areas, so that N95 masks can be preserved for healthcare professionals.

ii. Surgical Mask: These masks are also known as medical mask or procedure mask. It is 
supposed to be wore by healthcare professionals during surgery in order to stop bacteria in liquid droplets and aerosols emerged from the surgeon mouth or nose to enter the patients' open wound. These masks covers nose, mouth and chin of the wearer. Although these masks are better than a cloth mask but still very less effective in preventing the wearer from getting infected because of its inability to filter small particles and lose fitting causing leakage from sides. Its main purpose is to restrict the spread of large virus loaded droplets coming out from the mouth of an infected wearer during cough or sneeze. A surgical mask with an electret layer also have the ability to capture small particles by electrostatic attraction and thus is more effective than the one without electret layer.

iii. N95 Masks: These are circular or oval shaped masks with a tight fit to restrict air leakage from sides. These masks are made up of tough yet flexible non-woven polypropylene fiber. These mask can remove $95 \%$ of the contaminated particles of size more than 3 micron if wore properly. These masks have been proved very infective in protecting the wearer from getting infected. Due to limited supply and high demand during pandemic, these masks are recommended only for healthcare workers. The major disadvantage of these masks is that, it make breathing difficult due to less supply of oxygen and hence can cause discomfort to the wearer, if used for a longer duration of time. Another variant of N95 masks with exhalation valve for quick dissipation of exhaled air minimizes breathing related issues.

(a)

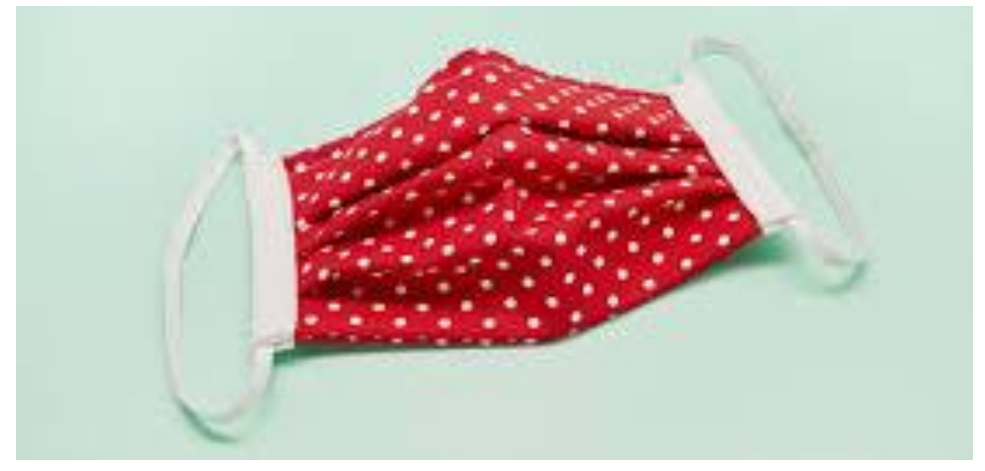


(b)

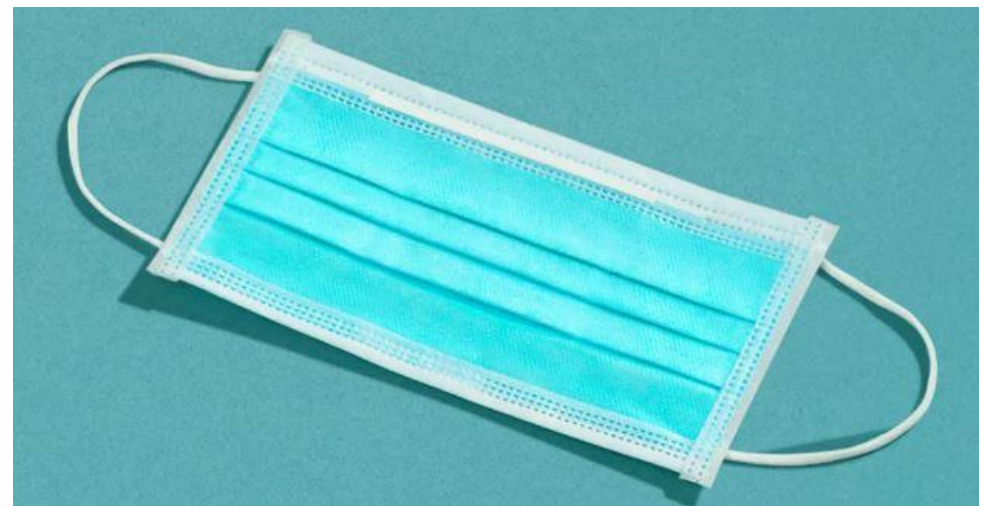

(c)

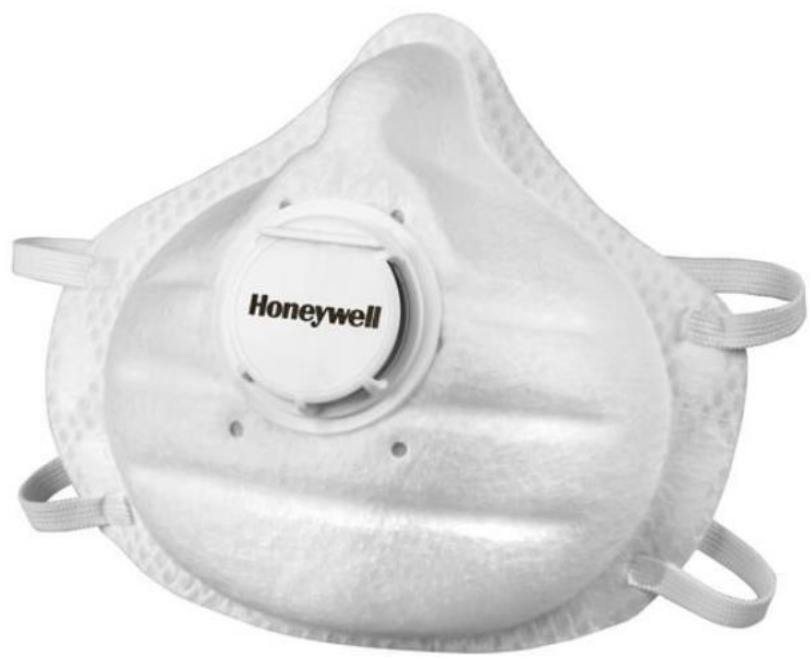

Fig 2: (a) Cloth Mask, (b) Surgical Mask and (c) N95 Mask [5], [6], [7]

This paper have five subsections, the first three subsection discuss about pandemic and its control whereas the last two subsection is focused on face masks. First subsection consists of comparative study of different coronavirus outbreak. The second is focused on current pandemics and its effects across the globe. The third subsection is the compilation of various studies on the role of preventive measures in the control of a pandemic. The efficiency of masks in controlling the spread of virus has been discussed in fourth subsection. This subsection also contains the comparative study of different masks. The last subsection showcase various novel face mask design that have emerged during current pandemic.

\section{Effect of coronaviruses (SARS-CoV, MERS-CoV and SARS-CoV-2) across the globe:}

Coronaviruses are a family of RNA viruses which is responsible for causing diseases in humans related to respiratory system. [3]. Although there are various coronavirus have been found in the past but three coronavirus namely SARS-CoV, MERS-CoV and SARS-CoV-2 caused serious impact on society. The details about these viruses are shown in Table 1.

\begin{tabular}{|l|l|l|l|}
\hline Virus & SARS CoV & MERS CoV & SARS CoV-2 \\
\hline
\end{tabular}


Proceedings of International Conference on Advances in the Field of Health, Safety, Fire, Environment \& Allied Sciences (HSFEA 2020).

\begin{tabular}{|c|c|c|c|c|c|c|}
\hline First Case & \multicolumn{2}{|l|}{2002} & \multicolumn{2}{|l|}{2012} & \multicolumn{2}{|l|}{2019} \\
\hline Last Case & \multicolumn{2}{|l|}{2003} & \multicolumn{2}{|c|}{$\begin{array}{l}\text { Few (17) cases were last } \\
\text { reported in Jan } 2020\end{array}$} & \multicolumn{2}{|l|}{ Ongoing } \\
\hline $\begin{array}{l}\text { Origin } \\
\text { Country }\end{array}$ & \multicolumn{2}{|l|}{ China } & \multicolumn{2}{|l|}{ Saudi Arabia } & \multicolumn{2}{|l|}{ China } \\
\hline \multirow[t]{2}{*}{ Hosts } & Natural Host & Bat & Natural Host & Bat & Natural Host & Bat \\
\hline & $\begin{array}{l}\text { Intermediate } \\
\text { Host }\end{array}$ & $\begin{array}{l}\text { Civet } \\
\text { Cat }\end{array}$ & $\begin{array}{l}\text { Intermediate } \\
\text { Host }\end{array}$ & $\begin{array}{l}\text { Dromedary } \\
\text { Camels }\end{array}$ & $\begin{array}{l}\text { Intermediate } \\
\text { Host }\end{array}$ & - \\
\hline $\begin{array}{l}\text { Mode of } \\
\text { Transmission }\end{array}$ & \multicolumn{2}{|c|}{$\begin{array}{l}\text { Person to person } \\
\text { through respiratory } \\
\text { droplets and close } \\
\text { contact. }\end{array}$} & \multicolumn{2}{|c|}{$\begin{array}{l}\text { Person to person through } \\
\text { respiratory droplets and } \\
\text { close contact. }\end{array}$} & \multicolumn{2}{|c|}{$\begin{array}{l}\text { Person to person } \\
\text { through respiratory } \\
\text { droplets and close } \\
\text { contact }\end{array}$} \\
\hline Symptoms & \multicolumn{2}{|c|}{$\begin{array}{l}\text { Fever, } \quad \text { Malaise, } \\
\text { Myalgia, Headache, } \\
\text { Diarrhoea, } \\
\text { Shivering }\end{array}$} & \multicolumn{2}{|c|}{$\begin{array}{l}\text { Fever, Chills, Myalgia, } \\
\text { Cough, Shortness Of } \\
\text { Breath, Nausea, Vomiting, } \\
\text { And Diarrhoea. }\end{array}$} & \multicolumn{2}{|c|}{$\begin{array}{l}\text { Fever, } \\
\text { Shortness of Breath, } \\
\text { Headache }\end{array}$} \\
\hline \multirow[t]{2}{*}{$\begin{array}{l}\text { Incubation } \\
\text { Period }\end{array}$} & Range & $\begin{array}{l}1 \text { to } \\
13 \\
\text { Days }\end{array}$ & Range & $\begin{array}{l}2 \text { to } 15 \\
\text { Days }\end{array}$ & Range & $\begin{array}{l}2 \text { to } \\
14 \\
\text { Days }\end{array}$ \\
\hline & Average & $\begin{array}{l}4 \\
\text { Days }\end{array}$ & Average & 5 Days & Average & $\begin{array}{l}5 \\
\text { Days }\end{array}$ \\
\hline $\begin{array}{l}\text { No. of } \\
\text { Countries } \\
\text { affected }\end{array}$ & \multicolumn{2}{|l|}{26} & \multicolumn{2}{|l|}{27} & \multicolumn{2}{|l|}{ More than $180^{*}$} \\
\hline $\begin{array}{l}\text { Majorly } \\
\text { affected } \\
\text { regions }\end{array}$ & \multicolumn{2}{|c|}{$\begin{array}{l}\text { China, Toronto in } \\
\text { Canada, Hong Kong, } \\
\text { Singapore, Hanoi in } \\
\text { Viet Nam }\end{array}$} & \multicolumn{2}{|c|}{$\begin{array}{l}\text { Saudi Arabia, United Arab } \\
\text { Emirates, and the Republic } \\
\text { of Korea }\end{array}$} & \multicolumn{2}{|c|}{$\begin{array}{l}\text { USA, Russia, Spain, } \\
\text { Italy, UK, Brazil, } \\
\text { France, Germany, } \\
\text { Turkey, Iran and } \\
\text { India* }\end{array}$} \\
\hline No. of cases & \multicolumn{2}{|l|}{$8000+$} & \multicolumn{2}{|l|}{2519} & \multicolumn{2}{|c|}{ Approx 5.6 Million* } \\
\hline No. of Deaths & \multicolumn{2}{|l|}{$800+$} & \multicolumn{2}{|l|}{866} & $\begin{array}{l}\text { Approx } \\
\text { Thousand* }\end{array}$ & 348 \\
\hline $\begin{array}{l}\text { Infection } \\
\text { Fatality Rate }\end{array}$ & \multicolumn{2}{|l|}{ Approx. $10 \%$} & \multicolumn{2}{|l|}{ Approx. 35\% } & \multicolumn{2}{|c|}{$\begin{array}{l}3.4 \% \text { as on } 3^{\text {rd }} \text { March, } \\
2020\end{array}$} \\
\hline
\end{tabular}

Table 1: Details of SARS-CoV, MERS-CoV and SARS-CoV-2 , [8], [9], [10], [11]

*Data as on $23^{\text {rd }}$ May 2020

\section{Influence of current pandemic COVID-19 across the globe:}

Present pandemic COVID-19 is due to the spread of SARS CoV-2. This virus can be transferred from one person to other through respiratory droplet and contact routes [12]. Transmission of infected droplets can occur when a person is in close contact (less than $1 \mathrm{~m}$ ) with an infected person during coughing or sneezing. These droplets can enter into the body of a healthy person though mouth nose and eyes. Transmission may also occur through indirect contact with surfaces in the immediate environment or with objects used on the infected person [13]. The life span of SARS CoV-2 at different surface is given in Table 2. Although the virus 
cannot be spread by airborne transmission still as a safety measure WHO continues to recommend airborne precautions for circumstances and settings in which aerosol generating procedures and support treatment are performed, according to risk assessment. [14]

\begin{tabular}{|l|l|l|}
\hline S.No. & Surface & Life Span of SARS CoV-2 ${ }^{\#}$ \\
\hline 1 & Air & 3 Hours \\
\hline 2 & Copper & 4 Hours \\
\hline 3 & Cardboard & 24 Hours \\
\hline 4 & Stainless Steel & 2 -3 Days \\
\hline 5 & Polypropylene Plastic & 3 Days \\
\hline
\end{tabular}

Table 2: Life span of SARS CoV-2 on different surface. [15]

${ }^{\#}$ At $21^{0} \mathrm{C}$ to $23^{\circ} \mathrm{C}$ and $40 \%$ relative humidity

The SARS CoV-2 was first found in Wuhan City, Hubei Province of China in December 2019. As of 3 January 2020, a total of 44 patients with pneumonia of unknown etiology have been reported to WHO by the national authorities in China. In the next few week, the coronavirus cases were reported from different counties all over the globe. On 11 February 2020, WHO named this novel coronavirus disease as COVID-19. On $7^{\text {th }}$ March, 2020 the total number of cases due to COVID-19 outbreak reaches 100,000 mark. On $11^{\text {th }}$ March, 2020 WHO characterizes COVID-19 as a pandemic. Total number of COVID-19 cases and associated death throughout the world with time is shown in Fig 3(a) and 3(b) respectively. The percentage distribution of cases in various countries is shown in Fig 3(c). 
Proceedings of International Conference on Advances in the Field of Health, Safety, Fire, Environment \& Allied Sciences (HSFEA 2020).

(a)

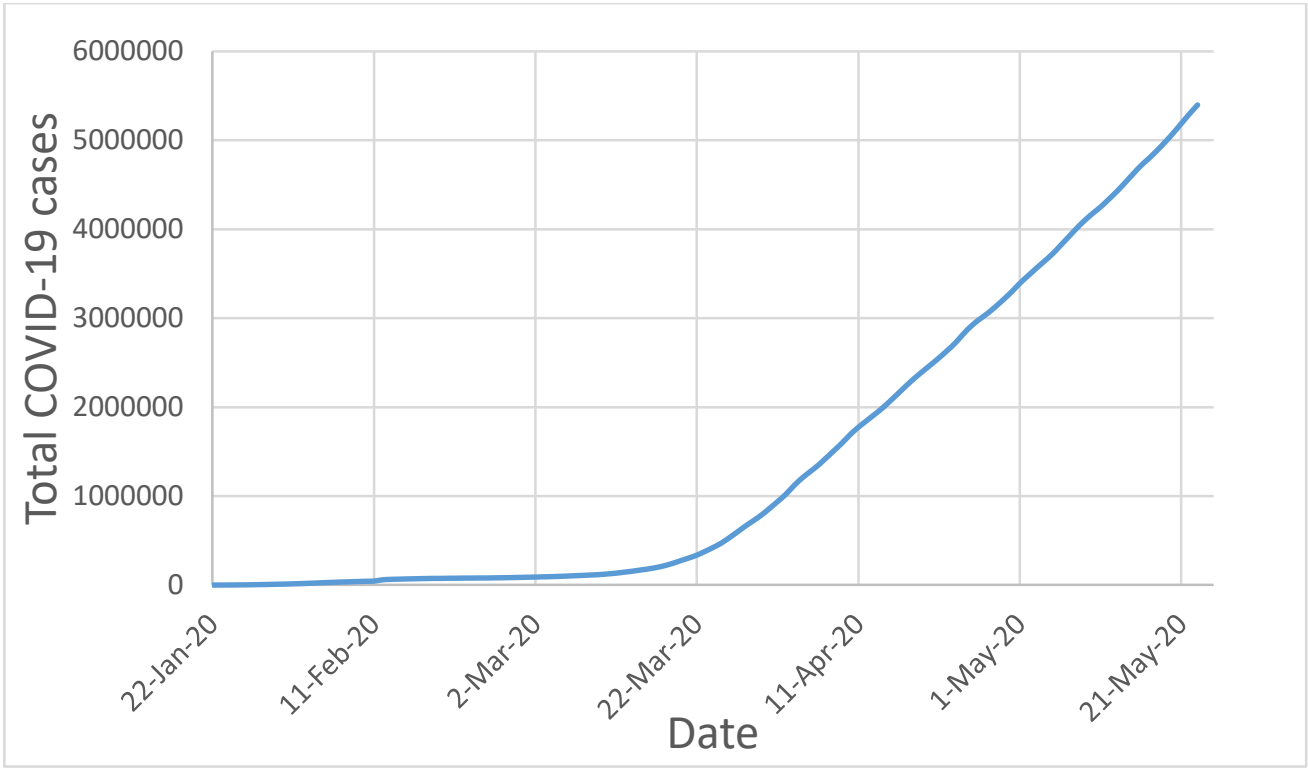

(b)

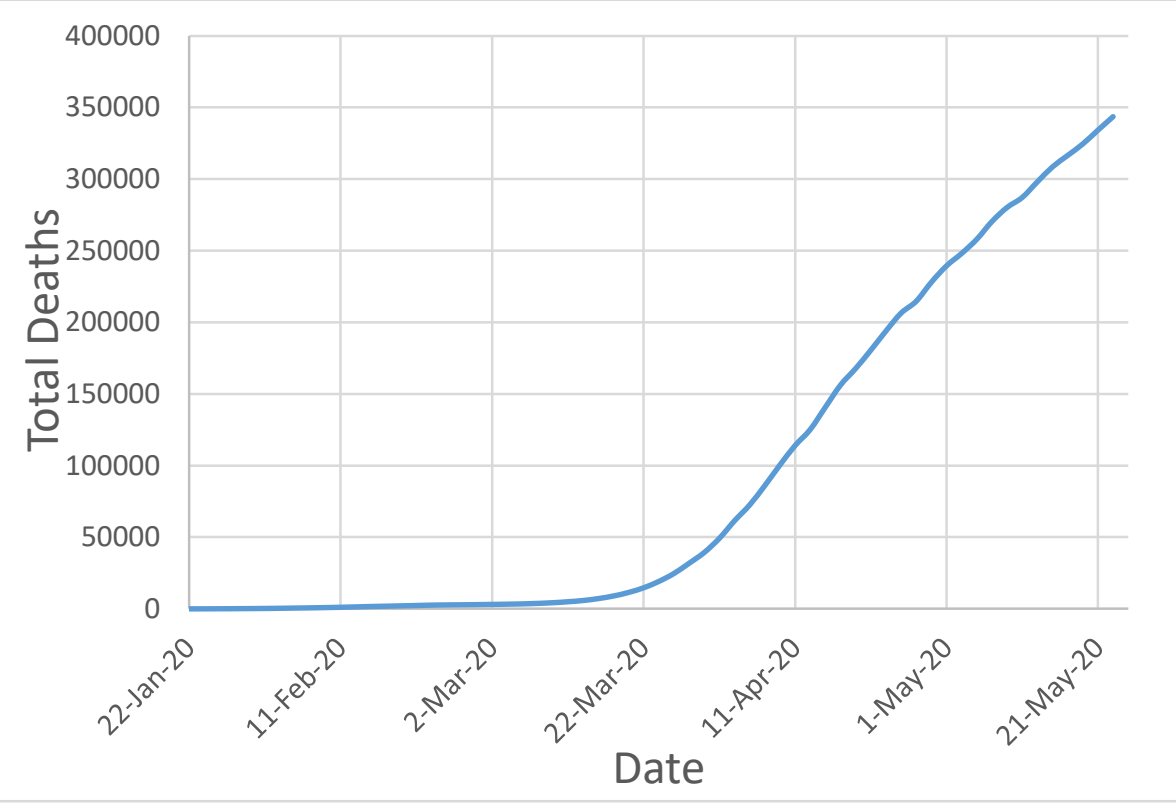


(c)

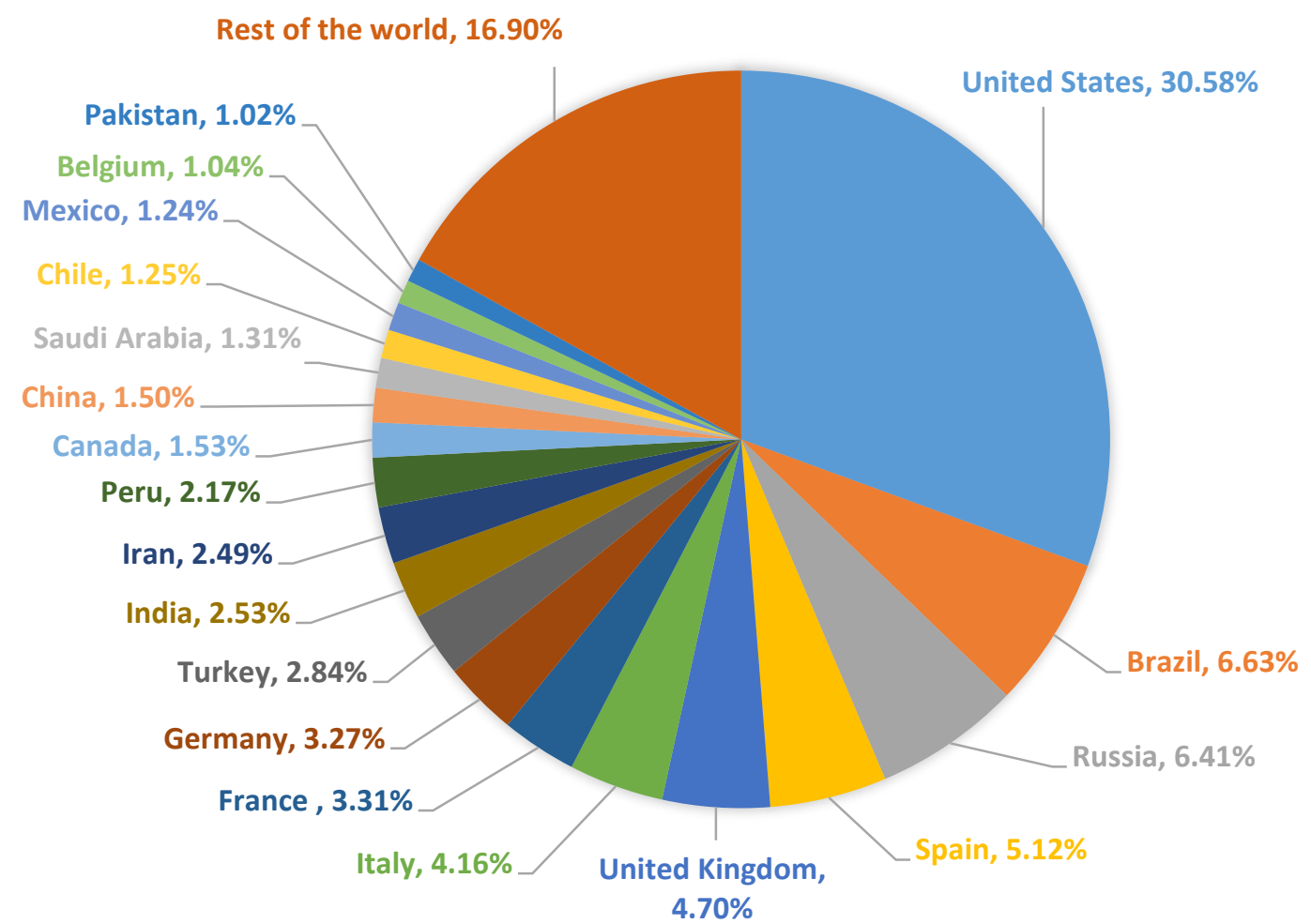

Fig 3: Statistical graph on COVID-19 outbreak (a) Increase in total number of COVID-19 cases across the globe with time*, (b) Increase in number of death due to COVID-19 across the globe with time*, (c) Country-wise distribution of COVID-19 cases across the globe* [16].* Data as on $23^{\text {rd }}$ May 2020

\section{Importance of adopting preventive measures during pandemic:}

WHO, CDC and government of different countries has issued advisory to the public for taking preventive measures during current pandemic. The advisory was majorly focused on wearing mask, maintaining social distance and washing hand frequently. In order to ensure social distancing government of various countries including USA, China, Italy, Spain, France, UK, India etc. has imposed complete lockdown during which civilians (excluding healthcare professional and those who are associated with essential services) cannot go outside their house except for essential activities like buying food items, medicine or in case of medical emergency etc. The importance of taking precautions can be well understood from fig 4 . 


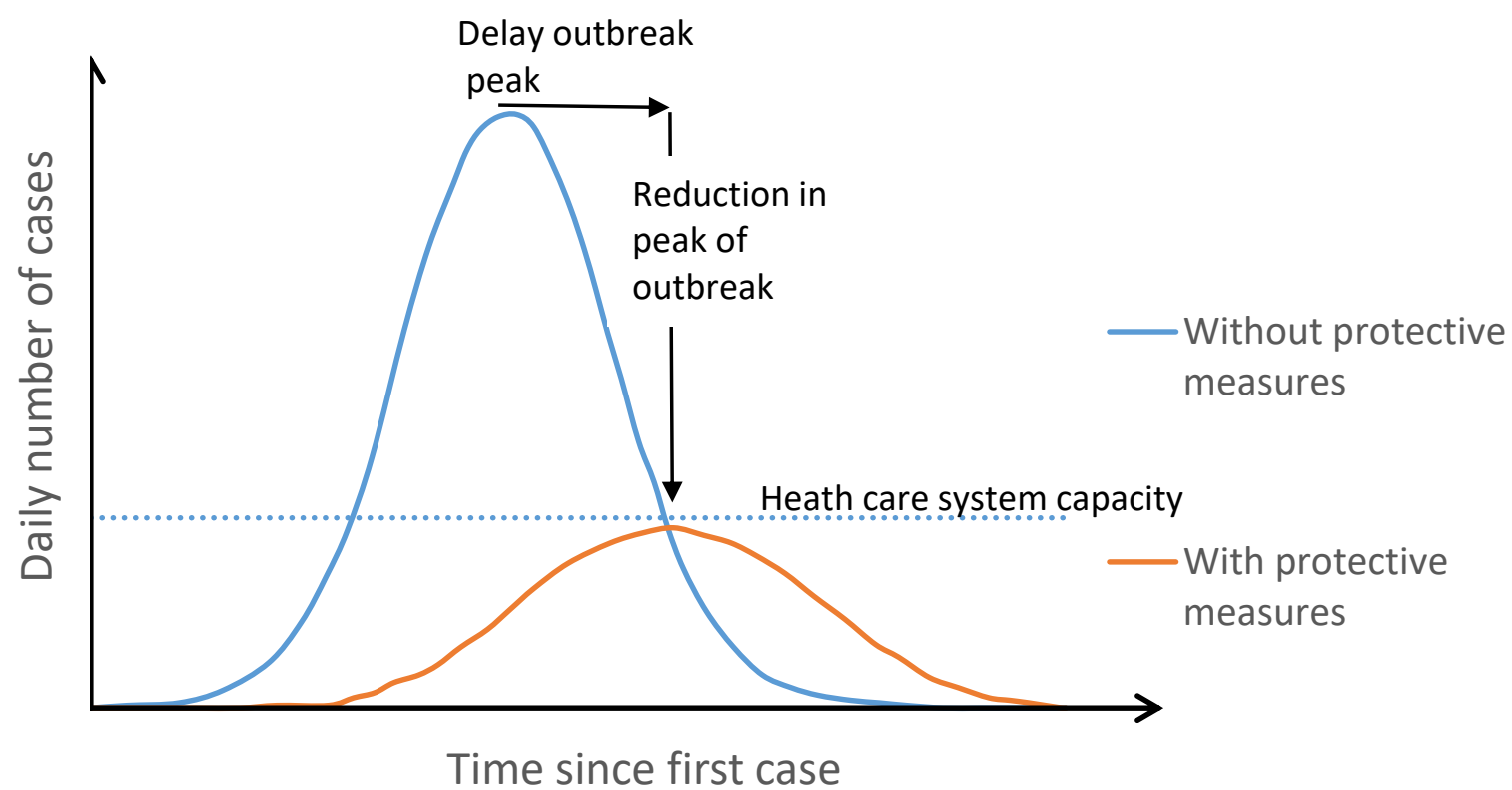

Fig 4: Variation in daily number of cases with and without protective measures. Source: CDC

The capacity of health care system of a country is limited and cannot handle sudden increase in the number of patient. This situation can cause many death due to lack of medicine and attention of medical personnel. By taking proper protective measures the peak of this curve can be flattened, such that the magnitude of requirement of the medical facilities remain under the health care system capacity. Protective measures also delays the of peak of the curve, which ensure that the government have enough time to increase the health care capacity by developing new testing facility, increasing number of beds in hospitals, opening new isolation centre etc. The total time to end a pandemic does increase by taking precaution measures but the reduction in total number of cases are far important than decreasing the time duration of the pandemic. A systematic review of physical intervention to reduce the spread of respiratory viruses (Table 3) clearly shows that the hand washing, wearing mask and gloves and maintaining social distance effectively reduce the spread of viruses. [17]

\begin{tabular}{|l|c|l|}
\hline \multicolumn{1}{|c|}{ Physical Intervention } & $\begin{array}{c}\text { Intervention } \\
\text { effective }\end{array}$ & \multicolumn{1}{|c|}{ Interpretation } \\
\hline Handwashing & Yes & Physically removes virus \\
\hline $\begin{array}{l}\text { Barriers ( Masks, Gloves, } \\
\text { Gowns, Goggles) }\end{array}$ & Yes & Prevent contact or inhalation of virus \\
\hline Social distancing & Probably & $\begin{array}{l}\text { Alters environmental conditions for } \\
\text { transmission }\end{array}$ \\
\hline Gargling & Probably & $\begin{array}{l}\text { Dilutes or neutralises virus (observation is } \\
\text { based on a single study) }\end{array}$ \\
\hline Adding antiseptics to & Unknown & May dilutes or neutralise virus \\
\hline
\end{tabular}


Proceedings of International Conference on Advances in the Field of Health, Safety, Fire, Environment \& Allied Sciences (HSFEA 2020).

\begin{tabular}{|l|l|l|}
\hline $\begin{array}{l}\text { barriers and hygiene } \\
\text { measures }\end{array}$ & Yes & $\begin{array}{l}\text { Removes virus and alters environmental } \\
\text { conditions for transmission }\end{array}$ \\
\hline Combined intervention & Yenthe spread of \\
\hline
\end{tabular}

Table 3: Main finding of systematic review of physical intervention to reduce the spread of respiratory viruses [17].

\section{Effectiveness of face mask during a pandemic}

The use of face masks along with proper hand hygiene and social distancing can be very effective in controlling a pandemic. WHO, CDC and different government has made the use of face mask compulsory in public places. Meta-analysis of observational studies provided evidence of a protective effect of masks and respirators against severe acute respiratory syndrome (SARS). Meta-analysis of randomized controlled trials (RCTs) indicated a protective effect of masks and respirators against clinical respiratory illness (CRI) and influenza- like illness (ILI). Compared to masks, N95 respirators conferred superior protection against CRI, but not ILI. [18]

Researchers have quantified the influence of wearing N95 facemasks in reducing the spread of influenza H1N1. The result obtained from the simulation are shown in Table 4. If we assume that the N95 mask are 50\% effective in reducing susceptibility and infectivity and $50 \%$ of the population wear them on the first day, the final percentage of infected people reduced from $73 \%$ to $2.7 \%$. [19]

\begin{tabular}{|c|c|c|c|}
\hline \multicolumn{2}{|c|}{ N95 Mask effectiveness } & \multirow{2}{*}{$\begin{array}{c}\text { Percentage of } \\
\text { population wear N95 } \\
\text { mask }\end{array}$} & \multirow{2}{*}{$\begin{array}{l}\text { Percentage of } \\
\text { population } \\
\text { infected }\end{array}$} \\
\hline $\begin{array}{l}\text { Reduction in } \\
\text { susceptibility }\end{array}$ & $\begin{array}{c}\text { Reduction in } \\
\text { infectivity }\end{array}$ & & \\
\hline $0 \%$ & $0 \%$ & None & $73 \%$ \\
\hline \multirow{3}{*}{$20 \%$} & \multirow{3}{*}{$20 \%$} & $10 \%$ & $56 \%$ \\
\hline & & $25 \%$ & $45 \%$ \\
\hline & & $50 \%$ & $38 \%$ \\
\hline \multirow{3}{*}{$20 \%$} & \multirow{3}{*}{$50 \%$} & $10 \%$ & $37 \%$ \\
\hline & & $25 \%$ & $14 \%$ \\
\hline & & $50 \%$ & $7.5 \%$ \\
\hline \multirow{3}{*}{$50 \%$} & \multirow{3}{*}{$50 \%$} & $10 \%$ & $20 \%$ \\
\hline & & $25 \%$ & $5 \%$ \\
\hline & & $50 \%$ & $2.7 \%$ \\
\hline
\end{tabular}

Table 4: Reduction in percentage of population infected in case of wearing N95 mask during pandemic influenza. [19]

The effect of wearing surgical mask to reduce spread of influenza H1N1 was also quantified and compared with N95 mask. The result shows that if we consider the effectiveness of surgical mask in reducing susceptibility and infectivity is $5 \%$ and $50 \%$ of the total population wear it, 
then the percentage of infected population decreases from $74 \%$ to $68 \%$ as shown in Table 5. It can also be concluded that N95 masks are far more effective than surgical masks in controlling pandemic influenza. [20]

\begin{tabular}{|c|c|c|c|}
\hline \multicolumn{2}{|c|}{ Surgical Mask effectiveness } & \multirow{2}{*}{$\begin{array}{l}\text { Percentage of } \\
\text { population wear } \\
\text { surgical mask }\end{array}$} & \multirow{2}{*}{$\begin{array}{c}\text { Percentage of } \\
\text { population } \\
\text { infected }\end{array}$} \\
\hline $\begin{array}{l}\text { Reduction in } \\
\text { susceptibility }\end{array}$ & $\begin{array}{l}\text { Reduction in } \\
\text { infectivity }\end{array}$ & & \\
\hline $0 \%$ & $0 \%$ & None & $74.61 \%$ \\
\hline \multirow{3}{*}{$2 \%$} & \multirow{3}{*}{$2 \%$} & $10 \%$ & $73.13 \%$ \\
\hline & & $25 \%$ & $72.68 \%$ \\
\hline & & $50 \%$ & $72.34 \%$ \\
\hline \multirow{3}{*}{$2 \%$} & \multirow{3}{*}{$5 \%$} & $10 \%$ & $71.85 \%$ \\
\hline & & $25 \%$ & $71.12 \%$ \\
\hline & & $50 \%$ & $70.49 \%$ \\
\hline \multirow{3}{*}{$5 \%$} & \multirow{3}{*}{$5 \%$} & $10 \%$ & $70.75 \%$ \\
\hline & & $25 \%$ & $69.40 \%$ \\
\hline & & $50 \%$ & $68.55 \%$ \\
\hline
\end{tabular}

Table 5: Reduction in percentage of population infected in case of wearing surgical mask during pandemic influenza. [20]

A mathematical model was constructed for a population comprised of three different age groups and assume that some individuals wear facemasks. The impact face masks could have had on the spread of pandemic (H1N1) 2009 was quantified and their cost effectiveness was examined. Based on present value of future earnings, hospital costs, and lost income estimates due to illness, it was found that an unmitigated pandemic could result in losses of nearly $\$ 832$ billion in the United State. It was concluded that the use of face masks by 10\%, 25\%, and 50\% of the population could reduce economic losses by $\$ 478$ billion, $\$ 570$ billion and $\$ 573$ billion respectively. [21]

The guidelines of WHO and CDC on wearing face masks during various outbreak of virus is shown in Fig 5(a) and 5(b) respectively. Due to the shortage of N95 masks during the COVID19 pandemic, CDC have recommended the use of cloth face mask in community setting to control the spread of virus. On the other hand, WHO have not recommended the use of cloth mask because of the reason that it is not medically tested. 
Proceedings of International Conference on Advances in the Field of Health, Safety, Fire, Environment \& Allied Sciences (HSFEA 2020).

(a)

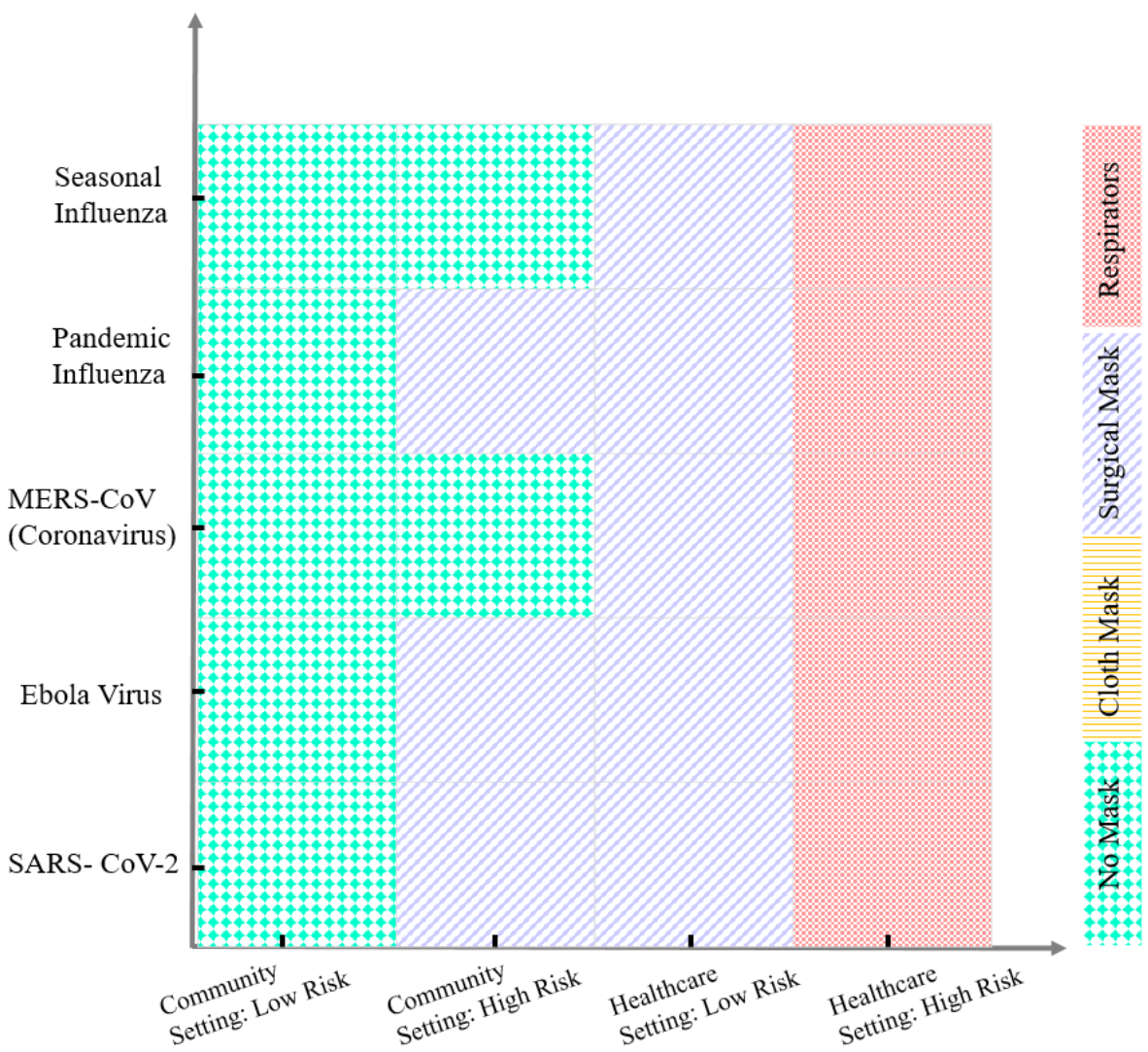

(b)

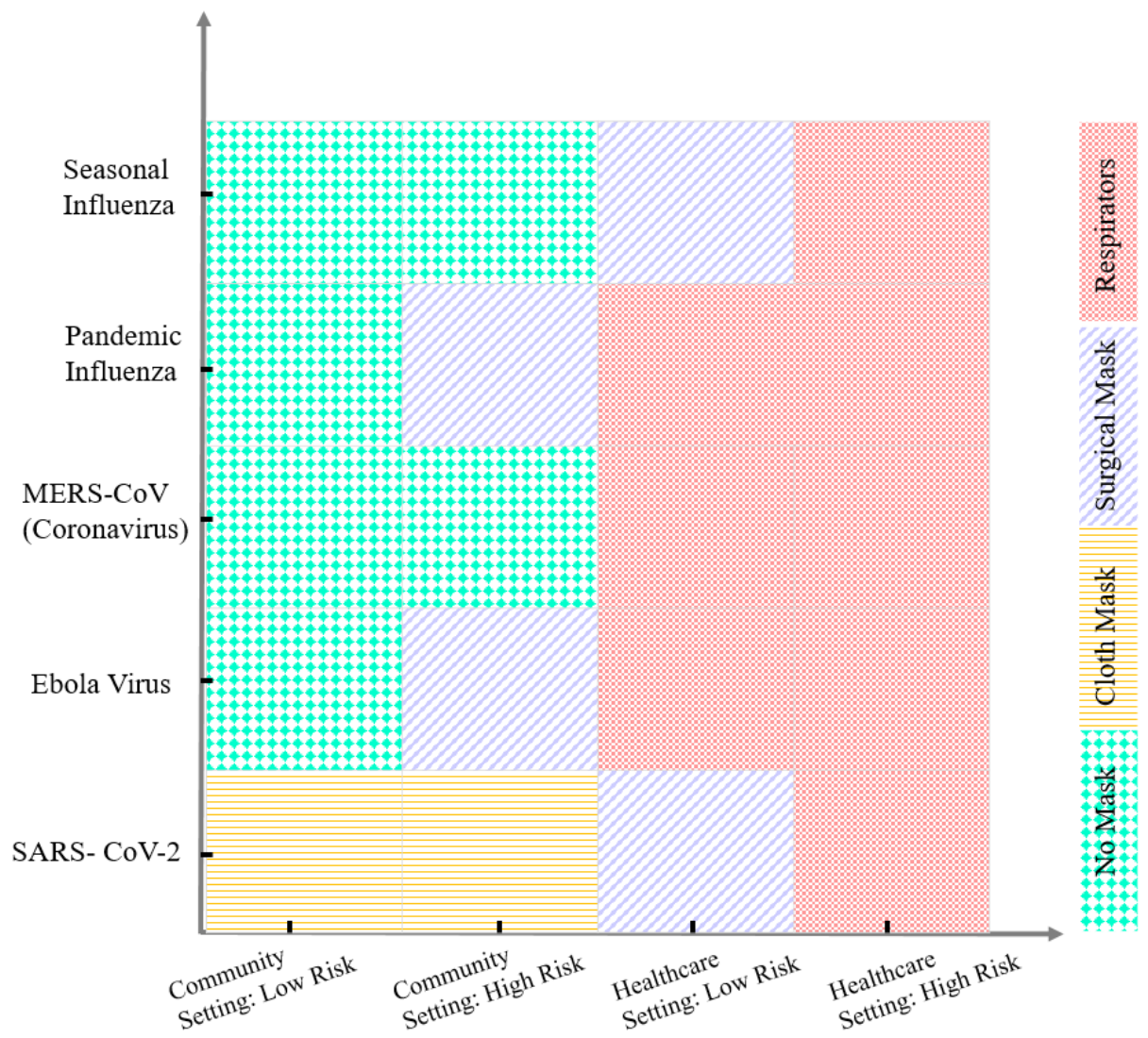

Fig 5: Infographic of guidelines on usage of face masks in various community settings during virus outbreak by (a) WHO and (b) CDC. [22], [23], [24] 


\section{Novel face mask design emerged during COVID-19 pandemic:}

During COVID-19 pandemic colleges, universities and research labs from all over the world have focused their attention on advancement of convention face mask. During this period many novel face mask were designed by various organizations. Due to the lack of availability of face masks, reusable silicon face masks and washable cloth face mask were manufactured by various industries [25]. Japan based Mitsufuji Corporation has manufactured reusable mask (Fig 6) that can be washed more than 50 times and used repeatedly to help alleviate the nationwide shortage of sanitary masks [26].

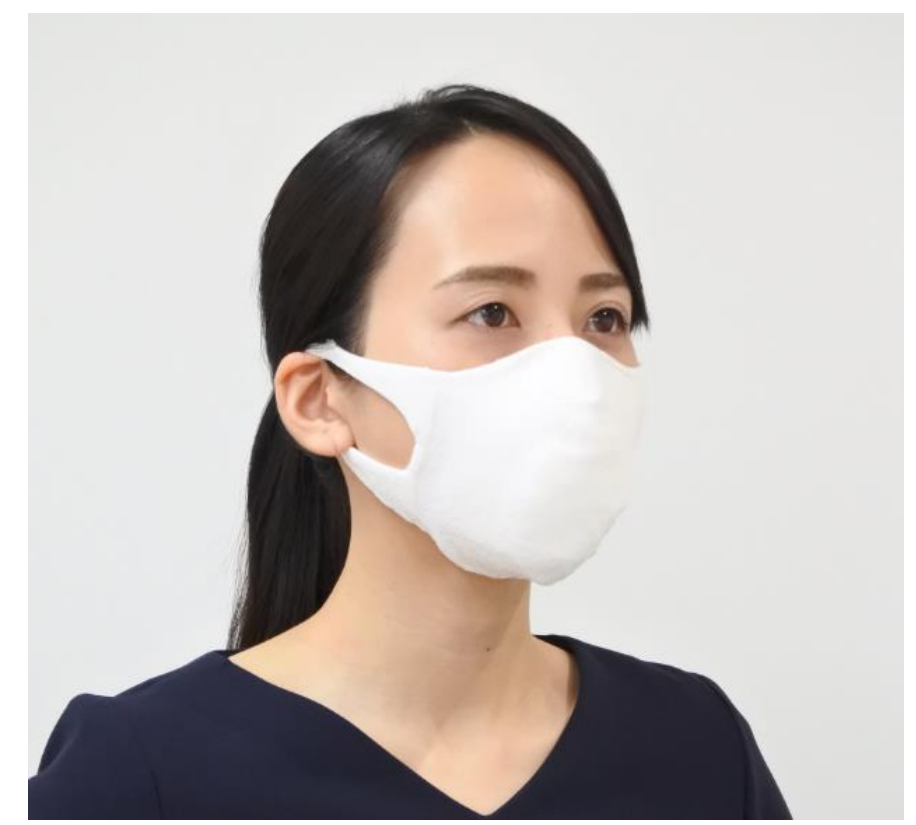

Fig 6: Reusable face mask designed by Mitsufuji Corporation. [26]

LIGC Applications has developed the Guardian G-Volt face mask (Fig 7) with a graphene filtration system with integrated electrical charge technology to repel viruses. These masks can be sterilized and safely re-used. [27].

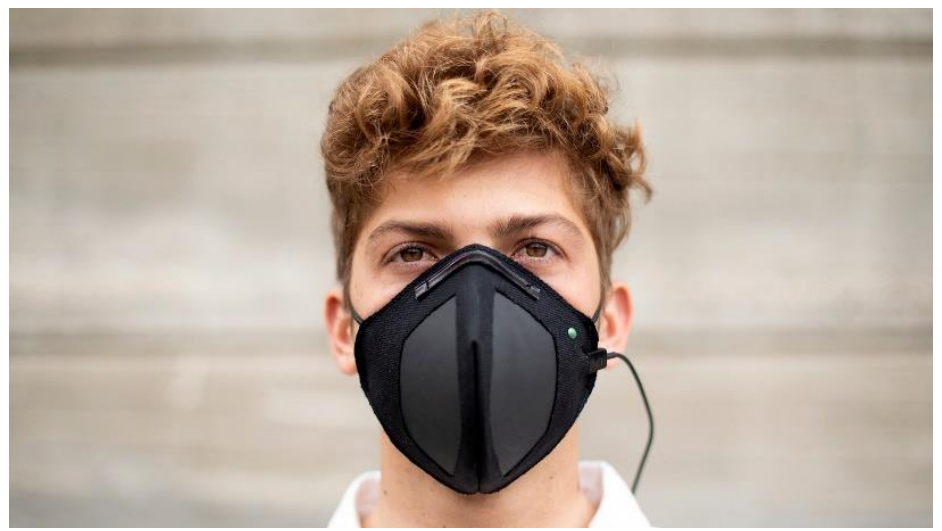

Fig 7: Guardian G-Volt face mask designed by LIGC Applications. [27] 
Microbiologist from University of Massachusetts Amherst invented a reusable facemask made out of copper, a material known to kill bacteria and inactivate respiratory viruses including the coronavirus [28]. An ear guard was developed to take the pressure off health care workers' ears from wearing masks all day [29]. Stanford University bioengineering associate professor Manu Prakash has modify full-face snorkel masks into reusable PPE for health care workers shown in Fig 8 [30].

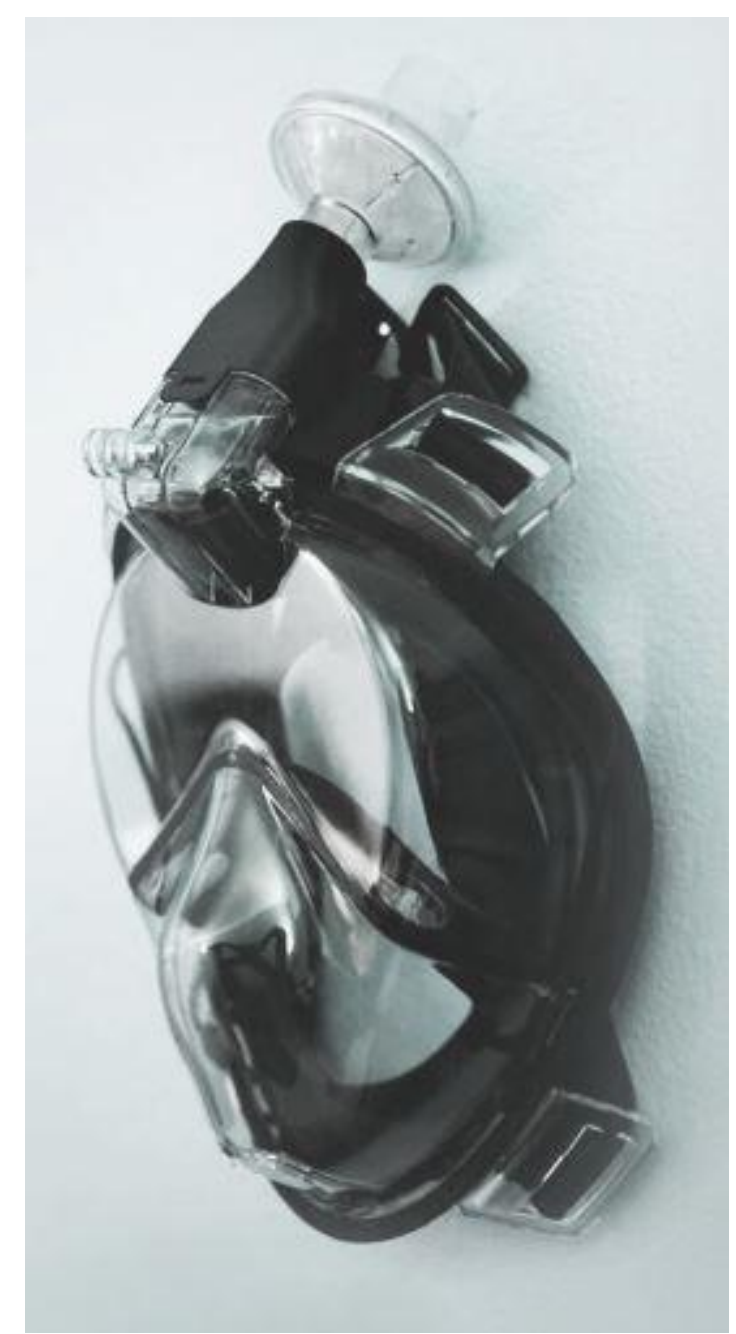

Fig 8: The reusable PPE design of the Pneumask project. [30]

Hyo-Jick Choi, a biomedical engineer and assistant professor at the University of Alberta has developed special salt-coated filters that can deactivate a pathogen like the coronavirus in few minutes [31]. Dr. Ashish Karn, faculty from University of Petroleum and Energy Studies have designed a COmfortably Vented, Indigenously Designed (COVID) Fabric Helmet (Fig 9) to curb infection spread in Education, Healthcare and other community settings [32]. The fabric helmet is integrated with many innovative design features to make it better fitted, comfortable, cheap, more protective and well ventilated. 
a)

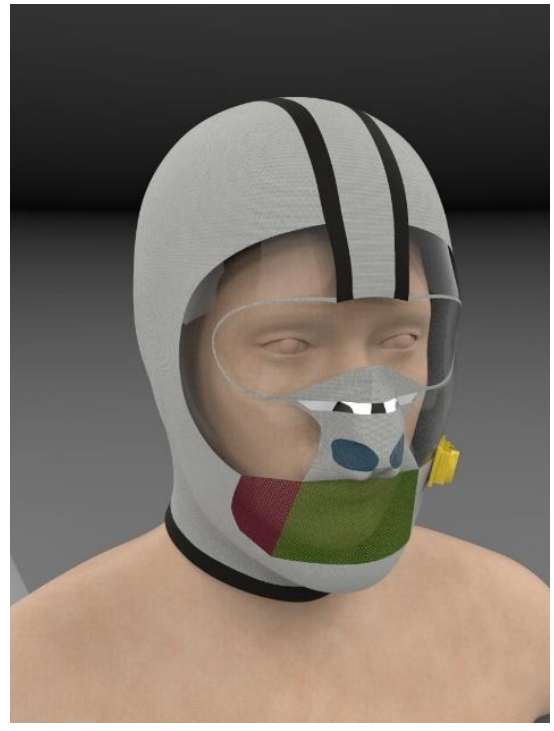

b)

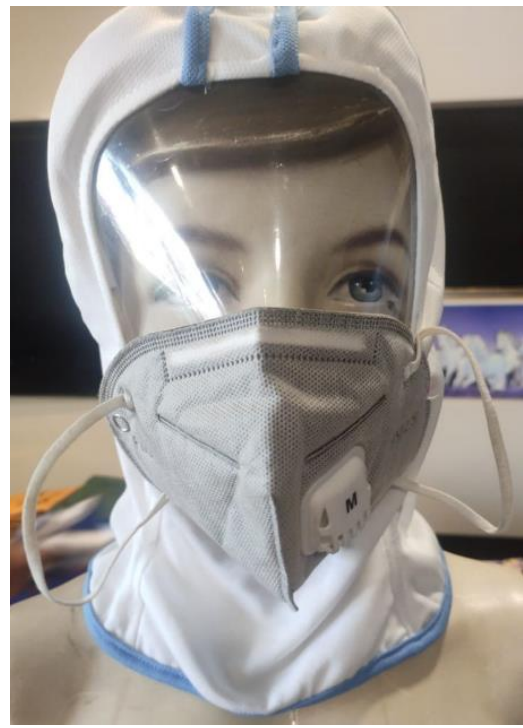

Fig 9: (a) A computer model showing a mannequin wearing a COVID Fabric Helmet , and (b) an actual prototype of COVID Fabric Helmet [32]

Efforts have been made toward designing customized face mask for all age groups because of the reason that an adult face mask is not effective for children due to poor fit. Mobile applications have been launched to get the 3D map of the face, in order to manufacture well fitted face mask for each face. During the pandemic, various DIY tutorials were made to easily make face masks using stuff which is readily available at home like paper towel, plastic bottle, cotton clothes etc. Researchers from the University of Cambridge and the University of Queensland have collaborated to create a special origami design for a face shield called the "HappyShield" [33]. As the mask became a part of daily wardrobe during the pandemic, various fashionable design for mask were also observed. 


\section{Conclusions}

This statistical data presented in this paper clearly shows that an outbreak of a pandemic is an alarming situation for the globe. SARS CoV, MERS CoV and SARS CoV-2 can cause severe respiratory related disease to human. SARS CoV-2 has infected around 5.6 million persons across the world and is responsible for more than 348 thousand death. Preventive measures can significantly decrease the transmission of virus from one human to another and is very effective in controlling the outbreak of a pandemic. Maintaining social distance, proper usage of mask and hand hygiene reduces the risk of spreading of infection in community. N95 face masks can remove $95 \%$ the contamination of size more than 3 micron and are most effective in preventive transmission of virus. Surgical masks on the other hand are ineffective in preventing the wearer due to lose fit which cause leakage from the sided, these masks are also incapable of filtering small droplets. Cloth masks although cannot provide higher degree of safety to the wearer but is effective in restricting transmission of virus from wearer to others. Due to lack of N95 masks, during the outbreak of disease, cloth masks can be used in community settings in order to preserve N95 masks for healthcare workers. During the pandemic, various novel design of face masks were developed. Some of the design emerged during COVID-19 pandemic are Guardian-G Volt Mask, Pneumask, COVID Fabric helmet and Happyshield. 
Proceedings of International Conference on Advances in the Field of Health, Safety, Fire,

Environment \& Allied Sciences (HSFEA 2020).

\section{References}

[1] B. W. Neuman et al., "Supramolecular Architecture of Severe Acute Respiratory Syndrome Coronavirus Revealed by Electron Cryomicroscopy,” J. Virol., vol. 80, no. 16, pp. 7918-7928, 2006.

[2] B. W. Neuman et al., "A structural analysis of M protein in coronavirus assembly and morphology," J. Struct. Biol. J., no. November 2018, 2011.

[3] J. Cui, F. Li, and Z.-L. Shi, "Origin and evolution of pathogenic coronaviruses," Nat. Rev. Microbiol., vol. 34, 2019.

[4] "Mechanisms Of Filtration," Air Quality Engineering, 2018. [Online]. Available: https://www.air-quality-eng.com/air-cleaners/filtration-mechanisms/.

[5] MU Health Care, "Cloth Face Masks: What You Need to Know," www.muheath.org. [Online]. Available: https://www.muhealth.org/our-stories/cloth-face-masks-what-you-need-know.

[6] Healthline, "Can Face Masks Protect You from the 2019 Coronavirus? What Types, When and How to Use," www.healthline.com. [Online]. Available: https://www.healthline.com/health/coronavirus-mask.

[7] Honeywell, "N95 Masks Explained," www.honeywell.com. [Online]. Available: https://www.honeywell.com/en-us/newsroom/news/2020/03/n95-masks-explained.

[8] WHO, "SARS (Severe Acute Respiratory Syndrome)." [Online]. Available: https://www.who.int/ith/diseases/sars/en/.

[9] Johns Hopkins Center for Health Security, "Coronaviruses: SARS, MERS, and 2019-nCoV," 2020.

[10] WHO, "Middle East respiratory syndrome coronavirus (MERS-CoV)." [Online]. Available: https://www.who.int/emergencies/mers-cov/en/.

[11] Worldometer, "COVID 19 updates." [Online]. Available: https://www.worldometers.info/coronavirus/.

[12] J. Liu, X. Liao, S. Qian, and Z. Z. Yuan J, Wang F, Liu Y, Wang Z, Wang FS, Liu L, “Community Transmission of Severe Acute Respiratory Syndrome Coronavirus 2," vol. 26, no. 6, 2020.

[13] S. Ong, Y. Tan, P. Chia, T. Lee, O. Ng, and et al Wong MS, "Air, Surface Environmental, and Personal Protective Equipment Contamination by Severe Acute Respiratory Syndrome Coronavirus 2 (SARS-CoV-2) From a Symptomatic Patient,” JAMA, pp. 3-5, 2020.

[14] WHO, "Modes of transmission of virus causing COVID-19: implications for IPC precaution recommendations," 2020. [Online]. Available: https://www.who.int/news$\mathrm{room} /$ commentaries/detail/modes-of-transmission-of-virus-causing-covid-19-implications-foripc-precaution-recommendations. 
Proceedings of International Conference on Advances in the Field of Health, Safety, Fire, Environment \& Allied Sciences (HSFEA 2020).

[15] “Aerosol and Surface Stability of SARS-CoV-2 as Compared with SARS-CoV-1,” 2020.

[16] Worldometer, "Coronavirus Worldwide Graphs." [Online]. Available: https://www.worldometers.info/coronavirus/worldwide-graphs/.

[17] T. Jefferson et al., "Physical interventions to interrupt or reduce the spread of respiratory viruses : systematic review," Br. Med. J., vol. 339, 2009.

[18] V. Offeddu, C. F. Yung, M. Sheau, F. Low, and C. C. Tam, "Effectiveness of Masks and Respirators Against Respiratory Infections in Healthcare Workers: A Systematic Review and Meta-Analysis," Clin. Infect. Dis., vol. 65, no. 11, pp. 1934-1942, 2017.

[19] J. Cui, Y. Zhang, Z. Feng, S. Guo, and Y. Zhang, "Influence of asymptomatic infections for the e ff ectiveness of facemasks during pandemic influenza," Math. Biosci. Eng., vol. 16, no. 5, pp. 3936-3946, 2019.

[20] S. M. Tracht, S. Y. Del Valle, and J. M. Hyman, "Mathematical Modeling of the Effectiveness of Facemasks in Reducing the Spread of Novel Influenza A ( H1N1 )," PLoS One, vol. 5, no. 2, 2010.

[21] S. M. Tracht, S. Y. Del, and B. K. Edwards, "Economic analysis of the use of facemasks during pandemic ( H1N1 ) 2009,” J. Theor. Biol., vol. 300, pp. 161-172, 2012.

[22] WHO, "Advice on the use of masks the community, during home care and in health care settings in the context of the novel coronavirus ( 2019-nCoV ) outbreak - Interim Guidance,” 2020.

[23] WHO, "Advice on the use of masks in the context of COVID-19 - Interim Guidance," 2020.

[24] CDC, "Recommendation Regarding the Use of Cloth Face Coverings, Especially in Areas of Significant Community-Based Transmission," 2020. [Online]. Available: https://www.cdc.gov/coronavirus/2019-ncov/prevent-getting-sick/cloth-face-cover.html.

[25] L. Dorn, "Kitchen Utensil Company Makes Reusable Silicone Face Masks to Help Personal Protective Gear Shortage," Laughingsquid.com, 2020. [Online]. Available: https://laughingsquid.com/gir-reusable-silicone-face-mask/.

[26] Mitsufuji Corporation, "Wearable Mitsufuji Launches 'hamon AG Mask," Mitsufuji.co.jp, 2020.

[Online].

Available:

https://www.mitsufuji.co.jp/en/information/hamonagmask_20200317/.

[27] "Guardian G-Volt masks would use graphene and electrical charge to repel viruses and bacteria," de zeen, 2020.

[28] University of Massachusetts Amherst, "Copper masks - a hopeful weapon against COVID19," University of Massachusetts Amherst, 2020. [Online]. Available: https://www.cns.umass.edu/news-events/news/copper-masks-hopeful-weapon-against-covid19.

[29] D. Ozdemir, "Boy Scout 3D Prints Numerous 'Ear Guards' to Help Medical Staff Suffering From Face Masks," Interestingengineering.com, 2020. [Online]. Available: https://interestingengineering.com/boy-scout-3d-prints-numerous-ear-guards-to-help-medical- 
Proceedings of International Conference on Advances in the Field of Health, Safety, Fire, Environment \& Allied Sciences (HSFEA 2020).

staff-suffering-from-face-masks.

[30] “The Pneumask Project.” [Online]. Available: https://www.pneumask.org/.

[31] L. Grant, "Inventor of virus-killing mask needs funding," 660citynews.com/, 2020. [Online]. Available: https://www.660citynews.com/2020/04/07/inventor-of-virus-killing-mask-needsfunding/.

[32] A. Karn, S. S. Deo, and A. Kumar, "A COmfortably Vented, Indigenously Designed (COVID) Fabric Helmet to curb infection spread in Education, Healthcare and other community settings," SSRN, 2020.

[33] HappyShield, "HappyShield," happyshield.github.io, 2020. [Online]. Available: https://happyshield.github.io/en/. 